\title{
Democracy in a Diverse Society: An Enigma of Socio-Political Development in Pakistan
}

\author{
Kishwer Khan*
}

\begin{abstract}
Democracy is a system of the government in which things and affairs are shaped and run according to the general will. In this system, the will of majority matters and minorities' rights are protected through a social contract agreed by all the stakeholders. In such a system, how much it is likely that the masses or the society should be homogenous, or it should be diversity controlling society? If the society is predominantly a diverse society, then how much are chances of development of democracy in such society and is it justified to say that diversity is a hurdle in the way of democracy if the latter is taken in lieu of majority's will? These are some of the questions directly attached to the issue of national integration and the development of democracy in Pakistan. Pakistan is a very diverse country by all means. It has a colossal diversity of race, ethnicity, religion, culture and so on. With this huge diversity, it was created as a single separate country in 1947, with vivid ideas of democracy and federalism. However, since the time of its inception, these are the same ideals that suffered the most. The annals of history suggest that Pakistan is a democratically failed state with intermittent authoritarian rules, the secession of its one province in 1971, and multiple separatist movements still going on in various regions of the country. Deprivation and exploitation lie as the root cause of this failure which ultimately marked the very process of national integration. Historical accounts tell that whenever the question of national integration was raised, it was dealt with the rhetoric of 'unity in uniformity'. This flawed notion of unity in uniformity itself suggests that among all the hurdles in the way of democracy, diversity is the biggest one. Is diversity really an obstacle in the way of development of democracy and national integration? This paper is intended to find out the answer to these questions and also aims to investigate the positive correlation between democracy and diversity for the cause of national integration and democratic development in Pakistan.
\end{abstract}

Key Words: Democracy, Diversity, Federalism, National Integration

* Assistant Professor, Department of History, University of Karachi 


\section{INTRODUCTION}

Democracy is a system of government which is run by the general will. It is meant for the protection of the rights of all the citizens. All the nation states tend towards democracy mainly because of its capacity and prospects to secure and develop the rights of their citizens. That is a pre-requisite for national integration, which is ultimately aimed for the security, survival and the development of the state. However, this pre-requisite appears as a thorny task to achieve if there is diversity or segregation in the society. There is a commonly held belief that diversity dims the prospects of democracy. And interestingly, this belief can be proven true by citing many examples of states, where democracy got failed. Pakistan is one of those countries who serve as the best example of this common belief. It is predominantly a diverse country, having a collage of several types of diversity ranging from ethnic and religious to language and culture, even to the social and economic status of the citizens. It is also a country which is counted as a failed democracy.

It suffered the blow of secession and intermittent martial laws, coupled with the continuous separatist movements going on in various parts of the country. Some scholars of history of Pakistan argue that one of the causes of failure of democracy, is its colossal diversity, which actually manifested into violent conflicts between and among diverse groups of the society. These scholars share the views of many other thinkers, who aver that diverse societies are more prone to conflicts as compared to homogenous ones, therefore the prospects of democracy in such society appear so daunting. And, history of Pakistan offers so many evidences and examples to prove this view. Nevertheless, by referring to the counter narrative of this belief, the causes of failure of democracy in Pakistan, are more accounted to the malfunctioning and faulty implementation of democratic principles, than to the diverse composition of its society. Its history suggests that the founders of the country were well aware of the fact that the state they have been striving for, is going to be heterogenous one with colossal diversity of many types. Even then, they were determined to make it a democracy. They never had a doubt about its democratic system and institutions. But unfortunately, their dream went sour and Pakistan could not be a true or efficient democracy, not because of its diversity, rather due to many other factors including the denial of this diversity and flawed notion of 'unity in uniformity'.

The subsequent governments in Pakistan have been hammering the cause of uniformity or homogenization of all citizens, irrespective of their differences, for the very cause of national integration. They forgot or avoided the idea that democracy works with the general will, and the question of general will arises when there is a diversity of opinions. They misinterpreted the concept of integration with assimilation. Ultimately, there emerged an intolerance for otherness and differences, no respect for diversity and no room for disagreement. Even after the seven decades since the creation of the country, it is still roaming around the flawed notions of unity, different types of insecurity, inherent fear of 'majoritarian democracy' and above all, the wait for the 'right time' to make this country a democracy or a true Republic. Once the track of the democracy and development is set or shifted in the wrong direction, or from upside down, the country is moving there with all its vigour and dedication.

\section{Correlation between Democracy and Diversity}

Democracy is both the system and the concept of living together, of peaceful co-existence and of protection of rights of the individuals. Though, the crude form of definition of democracy implies the rule of people, the development of political ideas and institutions 
during the eighteenth and nineteenth centuries, modified the meaning and definition of democracy. Initially, the form of democracy, which was found during the times of Greek city-states, can be termed as 'direct democracy' where decisions were taken directly by the people. However, after the French and American revolutions, direct democracy seemed a bit unpractical mainly because of large number of masses.

Instead the architect of the democratic social contract, came up with the ideals of 'representative government', and thus the 'Republic' emerges. Nevertheless, with regard to the basic concept of democracy, the spirit of the system remains same, i.e. supremacy of general will. Which is essentially required for the very cause of national integration and development. However, this cause of national development and integration appear so blurred if there is huge diversity in the society. Diversity is a term used to describe the cultural, ethnic, racial, linguistic and religious differences of the people living in a state or a region. Many scholars argue that a diverse country is more prone to social and political conflicts as compared to the homogenous ones. They assert that diversity of any type or many types, makes the society vulnerable to conflicts, which ultimately hinders the way of democracy. These scholars like Donald Horowitz, M. S. Fish and Robert S. Brooks establish the negative correlation between democracy and diversity. They build this negative correlation on the basis of ethnic cleavages in a society, where democracy cannot be flourished with the presence of racial or ethnic diversity. Here, in this scenario, this is not actually diversity, which is hampering the way of democracy, rather it is the deprivation or fear of exploitation of weak by the dominant community, which makes a compromise very difficult to achieve. For instance:

Donald Horowitz makes a similarly encompassing argument in Ethnic Groups in Conflict. He proposes a psychological theory in which the source of ethnic conflict is competition for status. He takes as a given the existence of several discrete groups inhabiting the same state, differentially constituted by colonial influences but similar enough (and in close enough proximity) to make group comparisons frequent. Due to this particular arrangement, a group tends to see itself as the in-group and another as an out-group, along with the negative feelings inherent in this sociological relationship. The result is the perception on both sides of a special type of zero-sum game, in which the competition is over self worth rather than material goods. As each side asserts its superiority, it also fears (or envies) the other, and the stage is set for conflict. The prospects for a workable democracy may be weakened by the majority group's abuse of power, or even the minority group's fear of abuse, premised on the assumption that "political power held by members of one community would be used for the exclusive benefit of that community or to the detriment of other communities."

The idea that diversity is an impediment in the way of development of democracy, is centuries old. Many thinkers including John Stuart Mill share the same opinion. As Mill, in his book, "Consideration on Representative Governments", holds the view that democratic and free institutions are very difficult to be established in a heterogeneous society. ${ }^{2}$ This is

1. Donald Horowitz, Ethnic Groups in Conflict (Berkeley: University of California Press, 1985), 188, quoted in Scott Radnitz, The Tyranny of Small Differences: The Relationship between Ethnic Diversity and Democracy in the Former Socialist Bloc.

2. J. S. Mill, Consideration on Representative Governments (NewYork: Liberal Arts Press, 1958) 
absolutely an undeniable fact that most of the countries in the world are heterogeneous in some or many ways. No matter how many types of diversity is there, the governance of heterogeneity has been a herculean task for the state. Because, usually a diverse society suffers from a 'security dilemma', specially from dominant groups or community. Such dilemmas, sometimes, are manifested into violent conflicts, which eventually mark the very process of democracy and national development. It is true that somehow diversity creates the impediments in the way of social cohesion and democratic development. In heterogeneous countries, decision making at the national level appears to be a difficult task, as consensus building among all seems nearly impossible in presence of ethnic, linguistic or religious cleavages. As Steven Fish and Robin Brooks state,

A number of eminent political scientists have seen diverse societies as disadvantaged when it comes to democratization. According to many observers, ethnic differences divide society and make compromise and consensus difficult. Heterogeneity poses the risk of inter-communal violence, which can quickly undermine open politics. ${ }^{3}$

Apart from this point of view, there is a plethora of literature that suggests a contrasting view of co-relation between diversity and democracy. For the scholars, who see positive nexus between these two concepts, ethno-linguistic diversity serves better for democratic development. For example,

A handful of writers have argued that ethnic multiplicity may actually be good for controlling conflict and promoting democracy. In a recent study of Papua New Guinea, Benjamin Reilly asserted: 'The primary reason for PNG's democratic success is the sheer diversity of its ethnic structure, which virtually guarantees that no one group is able to single-handedly monopolize political power'.

The positive correlation between diversity and democracy is seen in the capacity of the concept of democracy, which can accommodate the diversity effectively. History of the world suggests that democracy as a system of government was presented against the hegemony or dictatorship of a person or a few. It was meant for the will of masses who were more in number but less in power to exercise their will. Therefore, to counter the tyranny of one or of a dominant group, the concept of direct democracy was introduced, which later on developed into representative government. Thus, among all the systems of the government, democracy offers some feasible strategies to deal with the threats of hegemony or dictatorship, by upholding the rights of individuals and by accommodating the diversity into mainstream politics and administration. As Valerie Bunce argues,

In theory at least, democracy would seem to be the best type of polity to deal with cultural diversity. This is because democracy is based upon certain principles that maximize inter-group trust and cooperation and, thus, the peaceful resolution of conflict - in particular, political equality; legal guarantees of political rights and civil liberties; free, fair and competitive

3. M. Steven Fish and Robin S. Brooks, Does Diversity Hurt Democracy? At muse.jhu.edu/article/51178 Downloaded: 22/04/2019 5:56pm

4. Benjamin Reilly, 'Democracy, Ethnic Fragmentation, and Internal Conflict: Confused Theories, Faulty Data, and the "Crucial Case" of Papua New Guinea', International Security, Vol. 25, No. 3 (2000/01), p. 168. Quoted in, M. Steven Fish and Matthew Kroenig, Diversity, Conflict and Democracy: Some Evidence from Eurasia and East Europe www.polisci.berkeley.edu/sites/default/files/people/... Downloaded: 21/04/2019, 1:35pm 
elections; and representative and accountable government. Thus, democracy is an approach to governance that has the capacity to empower and reassure majorities and minorities. ${ }^{5}$

However, there are some scholars who criticise the system of democracy as the precursor of anarchy. For them absolute democracy cannot work with such a huge number of diverse people. They highlight the demerits of democracy specially in a diverse society, but such scholars actually criticise a specific form of democracy, i.e. 'majoritarian democracy'. Michael Mann, in his book "Darkside of Democracy, criticises the democracy with this specific aspect of majoritarian one. Robert Dahl's 'Poliarchy' is another example of this criticism and of negative correlation between democracy and diversity. He specifically points out this negative correlation with reference to ethnic and religious diversity. Ironically, this view is a very strong assumption that prevails in the society very commonly as compared to within academic discourse. As Steven Fish and Matthew Kroenig explains,

The belief that heterogeneity imperils democracy is even more salient in public discourse than it is in scholarly writing. Discussion in the media and among policy-makers on the failure of this or that experiment with democracy often mentions ethnic fractionalization or plurality of different ethnic groups as a culprit, just as poverty or the absence of a tradition of democratic governance also are often mentioned as culprits. Social composition is normally seen as affecting democracy via its influence on the probability of violent civil conflict. According to such thinking, more diverse societies are more prone to conflict, which in turn dims democracy's prospects. ${ }^{6}$

In contrast to them there are thinkers like, Arend Lijphart, who comes up with an alternative or counter of majoritarian democracy, i.e. 'consociational democracy'. Lijphart in his famous book, "Democracies in Plural Societies" and in his article "non-majoritarian Democracy", proposes the alternative of majoritarian democracy in order to cope with the malaise of it. As mentioned by Scott Radnizt,

Arend Lijphart, in Democracy in Plural Societies, advances the second mechanism for pluralism leading to weak democracy or democratic breakdown: the tendency of a majority communal group to distribute resources along ethnic lines or simply tyrannize the minority. Although Lijphart is fundamentally optimistic regarding the prospect for democracy in plural societies, he begins with the assumption that there is a danger if plural societies are left to their own devices. This necessitates an institutional solution-consociationalism. Lijphart, like others, assumes that group differences are already socially salient and prone to being politicized. ${ }^{7}$

Besides these authors, there are many others who profess the positive correlation between democracy and diversity, specially the ethnic diversity. For such scholars, it's not diversity, which hinders the way of democracy, rather it's the denial of diversity, which halts the

5. Valerie Bunce, Democracy And Diversity In The Developing World: The American Experience With Democracy Promotion, The National Council for Eurasian and East European Research. Washington D.C., 2005. At www.ucis.pitt.edu/nceeer/2005_819-03g_Bunce.pdf. Downloaded: 27/02/2019. 5:19pm

6. M. Steven Fish and Matthew Kroenig. Op.cit.

7. Scott Radnizt, op.cit. 
development of democracy. Its not diversity which brings conflicts into society, it's the denial or intolerance to diversity which actually compels the society into violent conflicts and obstruct the way of democracy. As Daniele Conversi argues,

The conflictive relationship between democracy and cultural diversity can be explored better by addressing the opposite logic of 'diversity denial'. Multiculturalism is the political and social practice based on the recognition, respect and promotion of cultural difference. Its opposite, the concept of cultural homogenization, should be intended as the denial of all of the above - and needs to be historicized through its fluctuating relationship with the practices of authoritarianism and democracy. ${ }^{8}$

Hence, there is no end to the debate over the negative or positive correlation between democracy and diversity, so, instead of lingering on this debate, there is a need of understanding and exploring the positivity among various concepts and systems for the welfare and good of all. As conflicts are embedded in social structure, institutional mechanisms and even in our personalities, therefore, the discourse and efforts must be made for the management, prevention and resolution of the conflicts. Human society as a whole, no matter homogenous or heterogeneous, is prone to conflicts and there is no universally acclaimed theory that holds heterogeneity solely responsible for conflicts and as an obstacle in the way of democracy. For this point, Valerie Bunce aptly remarks that,

Just as homogeneity does not necessarily promote either democracy or peace (as the cases of Armenia, Haiti and Somalia, for example, remind us), so heterogeneity does not lead invariably to intergroup conflict. A quick overview of political trajectories in one large region-post communist Eurasia since 1989--provides ample evidence that, just as new and highly heterogeneous countries emerging from larger, dictatorial states can be both peaceful and democratic (as in the cases of Latvia, Estonia and, less evenly, Slovakia), so relatively homogeneous countries from a similar point of political departure can be both unstable and undemocratic (Armenia and Russia)... Thus, diversity and democracy are neither inherently in tension nor inherently compatible. Historical legacies can be harmful or helpful, and changes in the environment can move societies and their political leaders toward the poles of either inter-group conflict or cooperation, dictatorship or democracy. ${ }^{9}$

Thus, the correlation between democracy and diversity, is somewhere negative and somewhere it appears positive. But the real matter of concern is that how this relationship is manifested and what outcomes it brings in the society. It is now a proven fact that in todays world, among all the systems of the governments, democracy is the most feasible and celebrated one. However, it can also be criticised in lieu of its demerits. If democracy is taken only as the method of heads count, and only the will of majority is considered, then the system is destined to fail. The major reasons of this failure would be grievances and reactions of those who might be the sufferers of marginalization, being the diverse group or the minority. So, for the very cause of development of democracy and national integration, it is necessary to make the system truly inclusive and dynamic in terms of catering the demands

8.Daniele Conversi, Majoritarian Democracy and Globalization versus Ethnic Diversity? Democratization, DOI:10.1080/13510347.2011.626947 http://dx.doi.org/10.1080/13510347.2011.626947 downloaded 22/04/2019. 09:27pm 9. Valerie Bunce, op.cit. 
and needs of all citizens irrespective of their diverse identities or affiliations. As upholds by Daniele Conversi,

Democracy as a process cannot be fulfilled by obtaining universal suffrage. It must continuously 'expand' into pluralistic deepening, by encompassing and enshrining the protection of minorities and their participation in all decision making that affects them. For most liberals, this is a matter of quality, rather than quantity: the extension of suffrage is meaningless if the practice of individual freedom is not simultaneously expanded through individually protective institutions. ${ }^{10}$

\section{Pakistan: A Diverse Democratic Country}

Pakistan is country which emerged on the world map as one of the most diversely populated countries. It was sought to be a democracy and federation by its forefathers, mainly because of its diversity. The founders of the country had already foreseen the heterogeneity of the land and people of the regions, they were struggling for, to form a new independent country. When Pakistan came into being in 1947, it had a colossal diversity of many types, ranging from geography and topography to ethnicity, religion and culture. In terms of geography, the country had four major provinces, i.e. East Pakistan (Bengal), Sindh, NWFP and the Punjab. Balochistan was also there but it was not given the full provincial status till 1970, and the East Pakistan was approximately thousand miles away from the main territory of the country. Besides the provinces, there were around 11 princely states (including Qalat, Bahawalpur, Khairpur and Swat etc.) from Indian sub-continent, who acceded to Pakistan. All these states and provinces had very different types of boundaries, size of land, mineral or natural resources and population.

If the topography of Pakistan is taken into account, this country is blessed with all physical features and attributes of the land, found on this planet. e.g., mountains, deserts, rivers, forests, plains and valleys etc. With regard to ethnicity and languages, there is a long list of spoken languages and ethnicities, including the major ones i.e. Punjabi, Sindhi, Urdu, Pushto, Balochi and Saraiki. If the diversity of religion is considered, there are numerous religions and belief found including Islam as the religion of majority. Nonetheless, the sects and factions of religions are also present here. In addition to that, Pakistan is the land of several cultures and civilizations. From Karachi to Gilgit or from Balochistan to FANA (Federally Administered Northern Areas), there is a collage of various cultures, who have their own distinct history, traditions, languages, cuisines and so on. Diversity of Pakistan is its peculiarity and it has been the basis of its foundation. The country has an interesting diversity, which is embedded somewhere in homogeneity. For instance, if the religion is homogenous among all muslims, they are different in terms of language, culture and race, e.g. in Sindh and Balochistan. If there is a diversity of languages and race, they are homogenous in culture, e.g. in Punjab. Similarly, if people are heterogeneous according to their religions, they are homogenous in their language or culture, like Hindus in Sindh or Sikhs in Punjab. This heterogeneity of Pakistan has been its distinct feature, but all the rulers tried to undermine it for the cause of national integration by the flawed notion of 'unity in uniformity'. However, the history of the land shows that all such efforts went into vain, as democracy cannot be flourished in a society where the citizens are deprived of their basic identities and fundamental rights. The diversity of Pakistan is the beauty and to an extent is the strength of it, which can be accommodated but cannot be supressed. This is diversity and

10. Daniele Conversi, op.cit. 
the vows of the founders of the country to safeguard it, that attracted the units to join the newly announced federation in a democratic way. It was the province of Sindh who pioneered to join Pakistan by passing a resolution from its elected provincial assembly. And then the various regions and princely states acceded to new federation with the hopes and prospects of democracy, autonomy and prosperity.

\section{Causes of failure of democracy and national development in Pakistan: Is Diversity Responsible?}

Pakistan had to be a democratic federation by all means and desires of the founders and of its people. But unfortunately, neither it could be a successful federation nor a democracy. So many reasons and factors can be discussed here to explain this failure of federalism and democracy, but the main element lies with the flawed policies and notions adopted for the very cause of national integration and development of democracy.

Soon after the creation of the country, the early rulers took some very crucial steps, which were perhaps the need or only option of the time but later on proved to be lethal for the national cause. For example, Jinnah's decisions to declare Urdu as the national language and to separate Karachi as the national capital form the province of Sindh. Declaration of Urdu as the national language was not appropriate at all from the perspectives of federalism and democracy. In 1947, Urdu was the language of just a handful of people who were still migrating from India to Pakistan and were not the part of the existing population of the country. So, making it as the national language was not acceptable for the people who were the existing population or were in majority. But it is argued by some scholars that it was the rational decision of the time, as at that moment, no language, spoken within the regions of Pakistan, was able to be national language. Because, all those languages were purely provincial languages, not spoken or understood in other provinces. Like Bengali in Bengal or Punjabi in Punjab. However, according to Jinnah, this decision of making Urdu as the national language, worked for the cause of avoiding provincialism in Pakistan. Moreover, the decision to separate Karachi as the national capital, from the province of Sindh, flared up the anti-state feelings among the native Sindhis, who already have turned against the policies of the national government over the issues of refugees' settlement and evacuee property distribution.

In addition to that, there were some other decisions or steps taken by Jinnah, which were proved as democracy retarding decisions and ultimately hampered the process of democratization and nation building to a greater extent. Highhandedness in NWFP and Balochistan over the orders of the Governor General can be cited here as the example of this statement. No actions of Jinnah can be justified here which actually daunted the democratic process in Pakistan, however, there can be a room for the positive assumptions that he did not have enough time to rectify the decisions he took under the pressure of need of the time or very turbulent circumstances, the country was going through. As in words of Allen Mcgrath,

With the arrival of independence, Jinnah himself appeared to be in a state of shock. Negotiating over the years to achieve Pakistan, when it was achieved, he realized that he had never expected to reach that goal in his life time and was vague as to what Pakistan would mean in operation. Once 
he had won his Pakistan, it was for those who came after him to make use of it and set new goals. ${ }^{11}$

The ruler who came after Jinnah were not concerned with the development of democracy or national integration, but only with their absolute power and unopposed authority. Ghulam Muhammad, Iskander Mirza and Ayub Khan were those rulers who came into power only for their vested interests and they did not have any regard for democracy. They all were from Punjab and Punjab was that province which emerged as the power center in the politics of Pakistan. The main reason of this dominance of Punjab was the growing presence of Punjabi speaking people in central bureaucracy and military, in majority. After the demise of Jinnah and Liaquat Ali Khan, the reins of power in Pakistan went into the hands of army and bureaucracy, which were the only strong and organized institutions in the country at that time. Moreover, with the 'martial race' notion of the British, the army of India and Pakistan, has been consisted of the soldiers mainly form Punjab and then NWFP.

Therefore, when military in Pakistan got the opportunity to enter the power corridors, people from Punjab came into dominance. Furthermore, the rulers after Jinnah, no matter from army or bureaucracy, were mainly Punjabis and were trained under the British rule in Punjab. Historically, the British has a very different legacy of the government in Punjab as compared to other provinces like Bengal. Unlike other provinces, the government of Punjab was run by the individuals, instead of regulations. These individuals were given the uninterrupted extended powers to rule. So, with this background, when people like Ghulam Muhammad or Ayub Khan came into power, they didn't have any regard to written laws, electoral process or democracy. As they just continued the legacy of centralization of power, authoritarianism and undemocratic practices of British, who have been their master trainer in pre-partition Punjab. The eminent scholar of Pakistan history, Lawrence Ziring accentuate this argument as,

The transfer of power established Pakistan as a parliamentary democracy but no consideration was given to its colonial history or its traditional background. Pakistan evolved from a history long involved with authoritarian modes of governance. Medieval rule, patriarchy, and monarchy permeated the region. The years immediately before partition had offered little hint of democratic norms and processes... The British never seriously tutored their subjects in the art of responsible government; nor were the people who were sent to rule the subcontinent given that charge. Law and order was the essential requirement of colonial administration and by most measures that objective was realized. The British departure from the subcontinent was by all standards peaceful and orderly. The same could not be said for what the colonial authority left behind. $^{12}$

Furthermore, besides the role of individuals, the unusual circumstances of initial times, delay in constitution making and general elections, adoption of flawed policies of assimilation or uniformity and intermittent martial laws further hindered the way of democracy in Pakistan. The annals of history of Pakistan suggest that,

all the efforts to make Pakistan a true democracy, were proved to make mockery of it. The list of causes of failure of democracy is quite exhausted

11. Allen Mcgrath, The Destruction of Pakistan's Democracy (Karachi: Oxford University Press, 1998) p. 01

12. Lawrence Ziring, Pakistan: At the Crosscurrent of History (Oxford: Oneworld Publications. 2003)p. 68 
and still it is increasing, but this fate of the system was set during the early years. No attention was made towards the diverse needs, interest and expectations of the citizens of the country. Two major diversities i.e. the ethnic and religious, suffered the most, in the name of national integration. In 1949, with the passage of The Objective Resolutions, the religious minorities stood against the laws of the state. This historic document has always been the matter of debate and criticism among the rank and file, but it is always made as the preamble of all the constitutions. The critics of this document term it is a deviation from the vision of Jinnah, who actually wanted to make Pakistan a secular democracy. ${ }^{13}$

Though, there is another long debate over Jinnah's actual vision of Pakistan, the Objectives Resolution is criticised as a departure from his words and ideals of making Pakistan a home to all citizens, irrespective of their cast, creed or religion. Hence, no matter this document is according to Jinnah's vision or not, it is a deviation from the principles of democracy and federalism. Because, it seems to impose a religion over the land and lives of those citizens as well, who are of different belief. Since then, many laws and policies are made in the country which actually victimized the religious minorities, no matter in theory they were meant for equal rights for all. For instance, Zia's islamization process after 1977's coup in Pakistan. The next democracy restraining action comes in 1953, when the Governor General Malik Ghulam Muhammad forced Khawajah Nazimuddin, the Prime Minister of the time, to resign form his post over the charges of maladministration and inefficiency. Though, he kept on urging to take a vote of confidence from the parliament, Ghulam Muhammad did not let him to do so. This forceful removal of a Bengali speaking minister by a Punjabi speaking Governor General further aggravated the tension between two provinces. As Ian Talbot asserts that,

The political and constitutional crises exacerbated the tensions between the provinces and the centre. The latter became increasingly identified with Punjab because of the region's dominance of the two main institutional structures of the state - the Army and the civil bureaucracy. Their senior echelons cast around for ways to deprive the East Bengalis of their democratic majority which, if effectively deployed, would threaten both the foreign policy orientations of Pakistan's guardians' and their domestic priorities. $^{14}$

Afterwards, the coffin of democracy was nailed again in 1954, when Ghulam Muhammad dissolved the first constituent assembly of Pakistan, which was working as the parliament too. He dissolved it using his arbitrary powers as the governor general. The dissolution of the first constituent assembly was the result of a tug of war between the governor general and the assembly over the quantum of powers of the governor general, that he was continuously increasing day by day. In 1955, the shattered edifice of democracy once again suffered a serious blow in the name of parity, by the formation of One Unit. It was the brain child of Iskander Mirza, the last governor general and then the first president of Pakistan. He ordered the amalgamation of all the provinces of the west Pakistan into one single province, i.e. The One Unit, headed by the Punjab. One Unit was a clear breach of democratic norms and federal principles. Through One Unit, not only the ethnic minorities in west Pakistan were

13. For details, the speech of Jinnah he delivered on 11th August 1947, at the session of the First Constituent Assembly of Pakistan

14. Ian Talbot, Pakistan: A Modern History (London: Hurst \& Company, 1998)p. 126 
deprived of their distinct identities, but the smaller provinces also lost their official status as a province to The Punjab. Formation of One Unit furthered the decay of democracy in Pakistan in the name of unity and equality. It can also be held responsible for the origin or exacerbation of the anti-state separatist movements in Pakistan. Lawrence Ziring also supports this stance as,

One Unit was a purely bureaucratic enterprise. It overrode western Pakistan's multi ethnic base and was aimed at depriving the provincial politicians of their significant influence. Moreover, in creating one administrative province from the original four, the civil-military institution believed it could ease east-west antagonism and hence nurture national unity. ${ }^{15}$

After One Unit, the last nail in the coffin of democracy was the imposition of first countrywide martial law in 1958, by General Ayub Khan, who boasted himself of as the saviour of the country against the corrupt and incompetent politicians. He claimed to secure the country from the clutches of corrupt politicians and tried to 'democratize' the country through his brand of democracy, manifested in the constitution of 1962, and implemented through the 'Basic Democracies' System. This system of 'Ayubian Democracy' was boasted of to bring the parity between two wings of the country. As Philip Oldeburg opines,

The idea of parity survived the army takeover of 1958: the electoral college of 'basic democrats' in Ayub's 1962 constitution was split fiftyfifty, East and West Pakistan. But the position of Bengalis continued to erode, as Pakistan's 'decade of development' wound up favouring West Pakistan for commercial and industrial development, making Est Pakistan in effect a raw material-exporting quasi-colony. ${ }^{16}$

Since then democracy never took roots in Pakistan, though, the country kept on moving with intermittent martial laws and some brief spans of so called democratic regimes. The political system in Pakistan is in tatters and its culture is wholly undemocratic. Those who have ruled and continue to rule the country never truly believed in democracy. Those who championed democracy turned out to be authoritarians. They merely used democracy as a slogan to attain power. ${ }^{17}$ With the title of 'failed democracy', Pakistan also suffered the tag of 'failed state', when in 1971, it witnessed the breakup of the East Pakistan, the largest province of it. The debacle of the East Pakistan, commonly termed as 'Dhaka Fall', can be attributed, interalia, to the fear and reluctance of its ruling authorities, towards the majoritarian democracy.

History of Pakistan and its movement vividly shows that the idea of 'majoritarian democracy' has been a nightmare for the Muslims of India, who later formed Pakistan. Muslims as minority in India, has always been threatened by Hindus' majoritarian democracy, professed by Congress, and this fear of them continued in post-partitioned Pakistan, but this time against Bengalis. It is so ironic that unlike the traditional history of the world, a separatist movement in Pakistan was started by the majority, who was deprived of its basic rights and representation. East Pakistan or Bengal, being the largest province of the country, wanted its due share and rational representation in administration and the government. But unfortunately, the ruling elite in the West Pakistan did not let them to have their basic and

15. Lawrence Ziring, op.cit., p. 71

16. Philip Oldenburg, India, Pakistan, and Democracy: Solving the Puzzle of Divergent Paths (Oxon: Routledge, 2010)p.74

17. Zafar Iqbal, 'Elitist Political Culture and the Perils of Democracy in Pakistan', in, Ravi Kaliya,(ed.), Pakistan:

From the Rhetoric of Democracy to the Rise of Militancy (India: Routledge, 2011)p.157 
just rights, which ultimately led to the breakup of the country. A majority stood against the minority for its rights and representation, and against the deprivation, exploitation and marginalisation at the hands of minority. This irony can be explained better with the inherent fear of minority against the 'majoritarian democracy', as discussed earlier.

Apart from these, the saga of failure of democracy in Pakistan continued even after the cessation of Bengal, after the third martail law and even during the so called democratic regimes. Since 1988, after the demise of Zia ul Haq, the country has witnessed another martial law by General Pervez Musharraf in 1999, bracketed by oscillatory democratic regimes of PPP and PML $(\mathrm{N})$. However, no serious efforts are witnessed by any of them to make this country prosperous or developed in any way.

\section{Prospects of Development of Democracy and National Integration with Diversity in Pakistan}

Pakistan can be termed as a failed democracy. The people who were/are responsible to make it a successful democracy, never tried to do it in true manner. For them, Pakistan has never been 'fit' or ready to become a democracy, because there have been so many hurdles in its democratic development, including the security threat and its colossal diversity. So, all the efforts they tried to make this country secure, were meant to unite the people with the flawed policy of 'unity in uniformity'. This rhetoric not only marked the development of democracy in the country but also shattered it very foundations. Democracy has become a far cry and the state is still struggling for its security and survival. The ruling elite should understand that, as according to Amartya Sen, 'A country does not have to be deemed fit for democracy; rather it has to become fit through democracy. This is indeed a momentous change, extending the potential reach of democracy to cover billions of people, with their varying histories and cultures and disparate levels of affluence. ${ }^{18}$ Thus, with the aim to secure country at the cost of its nation building and democratic development, the ruling elite kept on hammering the notion of unity by uniformity. Which eventually, led to the origin of several anti-state nationalist movements in the country. No lesson was learnt even after the debacle of the East Pakistan, and the persecution policies of the central government continued to marginalize the smaller provinces and minority groups of the society.

The ruling elite always portrayed the diversity as the big hurdle and challenge to the security and survival of the country, and it never tried to unite the people by inclusive and participatory government and administration. Rather, the subsequent regimes in Pakistan continued the colonial legacy of highly centralized system of the government. It is argued that, the system in post-colonial state was worse than the colonial one, as it was more centralized, brutal, interventionist and undemocratic. Ironically, colonial masters were the foreigners, but the post-colonial rulers were the indigenous fellow muslims and sons of the soil. Furthermore, one of the other causes of failure of democracy is the lack of democratic norms and culture in the country. The institutions and people of Pakistan do not like and practice democracy on their own levels. Even the political parties, lack democracy within their structure and working. A society where personal relationship, loyalty to the family, personality cult, feudalism, corruption, bad governance, poor economic growth, lack of tolerance and education is found inherently, democracy seems difficult to take root in such society. However, the prospects of making Pakistan, a successful democracy are not as much

18. Amartya Sen, “Democracy as Universal Value,” Journal of Democracy, 10, no. 3(1999): pp. 3-17.

https://muse.jhu.edu/ accessed 30/04/2019 
dim. Its not about to unite the people by offending their distinct identities, rather its about respect and celebrate their particular identities with the feelings of shared rule. They should be given their due share in administration and government of the country, equal access to all opportunities and a sense of partnership in all the domains of the government and politics. That all can be done if the democratic norms and federal principles are followed in all walks of life from theory to practice and from individuals to institutions. As Zafar Iqbal says,

A democratic society can be realized only when its individual members behave according to democratic norms and values. The elected governments in Pakistan have failed because the political actors did not adhere to the democratic spirit. Briefly, the political culture of Pakistan can be characterized as complex, traditional, and feudal. A range of factors, such as enduring traditional beliefs, feudal values, distorted perceptions, and weak political institutions, have shaped Pakistan's polity. ${ }^{19}$

\section{CONCLUSION}

Pakistan is a heterogeneous country by all the means, therefore its national integration should be based upon the notion of "unity in diversity". But this peculiarity of the country is severely denied and taken into the way round by the rhetoric of 'integration through assimilation'. Consequently, the country suffered the disasters of civil wars, cessation, anti-state separatist movements, frequent military coups and fake or bogus democratic regimes. No serious efforts were made to bring Pakistan at the right track of democratic development while retaining its diversity, which ultimately yielded the way of its national integration, socio-political and economic development. Thus, the persistent denial of diversity and focus on flawed notions of unity kept on daunting the national fabric. Eventually, neither national unity was achieved, nor democracy could be developed. The only things which grew and augmented, are the socio-economic disparities, hatred among the citizens and insecurity of all types in the society.

Finally, it can be concluded here that, diversity in Pakistan has never been the cause of its malaise and underdevelopment, rather it's the denial of this diversity and flawed notions of national unity, which actually hampered the way of democratic, social, economic and political development in the country. If this persistent denial of diversity and ground realities goes on, it would keep daunting the national bond to the extent of disaster and calamity. Besides these, there is a dire need of national education and awareness programme for the masses to promote democratic values and norms in their personal lives and civic culture.

19. Zafar Iqbal, op.cit p. 139 


\section{References}

Allen Mcgrath, The Destruction of Pakistan's Democracy (Karachi: Oxford University Press, 1998)

Amartya Sen, "Democracy as Universal Value," Journal of Democracy, 10, no. 3(1999): pp. $3-17$.

Benjamin Reilly, 'Democracy, Ethnic Fragmentation, and Internal Conflict: Confused Theories, Faulty Data, and the "Crucial Case" of Papua New Guinea', International Security, Vol. 25, No. 3 (2000/01), p. 168. Quoted in, M. Steven Fish and Matthew Kroenig, Diversity, Conflict and Democracy: Some Evidence from Eurasia and East Europe www.polisci.berkeley.edu/sites/default/files/people/

Daniele Conversi, Majoritarian Democracy and Globalization versus Ethnic Diversity? Democratization, DOI:10.1080/13510347.2011.626947 http://dx.doi.org/10.1080/13510347.2011.626947

Donald Horowitz, Ethnic Groups in Conflict (Berkeley: University of California Press, 1985), 188, quoted in Scott Radnitz, The Tyranny of Small Differences: The Relationship between Ethnic Diversity and Democracy in the Former Socialist Bloc.

For details, the speech of Jinnah he delivered on 11th August 1947, at the session of the First Constituent, Assembly of Pakistan.

Ian Talbot, Pakistan: A Modern History (London: Hurst \& Company, 1998)

J. S. Mill, Consideration on Representative Governments (New York: Liberal Arts Press, 1958)

Lawrence Ziring, Pakistan: At the Crosscurrent of History (Oxford: Oneworld Publications. 2003)

M. Steven Fish and Robin S. Brooks, Does Diversity Hurt Democracy? At muse.jhu.edu/article/51178

Philip Oldenburg, India, Pakistan, and Democracy: Solving the Puzzle of Divergent Paths (Oxon: Routledge, 2010)

Valerie Bunce, Democracy And Diversity In The Developing World: The American Experience With Democracy Promotion, The National Council for Eurasian and East European Research. Washington D.C., 2005. At www.ucis.pitt.edu/nceeer/2005_81903g_Bunce.pdf.

Zafar Iqbal, 'Elitist Political Culture and the Perils of Democracy in Pakistan', in, Ravi Kaliya,(ed.), Pakistan: From the Rhetoric of Democracy to the Rise of Militancy (India: Routledge, 2011) 